\title{
An Analysis of the Relationship Between Work-Life Balance and Productivity in Ghana
}

\author{
Dr. Ahmed Eid Mohamed Ghareeb, \\ Dean of Business and Technology School \\ Madina Institute of Science and Technology, Accra, Ghana \\ E-mail: ahmedeid82@yahoo.com; ahmedeid82@jcba.edu.sa
}

Received: April 18, 2019 Accepted: May 15, 2019 Online published: May 27, 2019

doi:10.5296/ijhrs.v9i2.14840 URL: https://doi.org/10.5296/ijhrs.v9i2.14840

\begin{abstract}
The study examines the relationship between work-life balance and Productivity among Employee in Medium Organizations in Ghana. The study adopts a quantitative research method. The data of 240 Employee respondents were analyzed using different statistical techniques such as reliability survey, descriptive of variable analysis, correlation analysis using the Statistical Package for Social Science (SPSS). The correlation results indicated that work-life balance is positively correlated with Productivity. also, for effective Productivity to be enhanced, the level of motivation needs to be improved.
\end{abstract}

Keywords: work-life balance, family-friendly policies, dedicating quality time to family, flexible work, productivity

\section{Introduction}

Before many companies have the idea that spending more time in the workplace is the best way for success, nowadays we find many companies applied another method which is helping in making a balance between work and personal life. We can define work-life balance as a way of living which helps people to achieve success in work by satisfaction in personal life It is a concept in which the satisfaction and happiness of an employee act as the power for their productivity at work. Nowadays it's challenging to make a balance between work especially the stressful one and the family. The percentage of working women is increasing in all fields, with this phenomenon they really strive to make a balance between their work duties and their personal life. Also, the ideas of sharing the responsibilities between the parents in a semi-equal way made burdens on men too, so both of working men and women want to have a balanced life in which they can succeed in both job and family. The findings show that unbalanced work-family life causes a decrease in family satisfaction (Frone, 
Barnes, and Farrell 1994; Aryee et al. 1999; Burke and Greenglass 1999; Carlson and Kacmar 2000), parental overload, delays and absenteeism in family, a poor performance in family roles and a lack of family member support (Adams et al. 1996; Frone, Yardley, and Markel 1997). According to (Aryee, 1992) organizations that focus only on employees' performance without giving consideration to helping employees in achieving work-life balance suffer from the low employees' performance. Managers have a great role in directing the known conflict between employee's work and family duties and needs by promoting a flexible working environment which evaluates achievements instead of achieving work schedules and hours, providing some special services for employees like having a small kindergarten room for toddlers and small kids inside the workplace. There are many ideas that could help in having a motivating work environment. There are also many studies which suggest that to have positive results, organizations must put into consideration balancing between work and non-work needs for all the employees whether they have a family or not (Dex and Scheibl 2001; Fu and Shaffer 2001; Rotondo et al. 2003). It's clear that there are three types of employees: those who have a family with children, those who have a family without having children and those who aren't married. All of these types need from organizations to put their personal needs into consideration while creating a high-quality working environment in order to have a good performance. Employee productivity is very important for the success of the company in today's globally competitive environment. So this research is working on the relation between work-life balance and productivity of employees.

\section{The Importance of Research}

This Study Identify the relationship between work-life balance and flexible work options and the productivity of employees in Ghanaian companies.

\section{Study Hypotheses}

This study adopted the following two hypotheses;

- There is a significant correlation between family-friendly policies and productivity.

- $\quad$ There is a significant correlation between dedicating quality time to family and productivity.

\section{The Aim of the Study}

This study aims at examining the significance of work-life balance and its relationship to productivity. And identifying to what extent can the employee maintain the best balance between work duties and his family responsibilities. Emaar Company, Al Medina company, Rana motors, Modern Multimedia company, Silver Star Auto Ltd. and AMS company have been selected as the study sample.

\section{Research Questions}

Pursuance to the aim of the study, the following questions will be adopted by the study to 
facilitate the achievement of the study aim:

-What is the effect of the family-friendly policies of the companies on productivity?

-What is the effect of dedicating quality time to the family of the employees on productivity at work?

-How can employees balance work and personal life to improve productivity?

\section{Literature Review}

Edwards and Rothbard (2000) rejected considering balance as a linking mechanism between work and personal life because we can not measure how experiences and duties in one role of them affect the duties and experiences of the other role. It's found that there is a strong interfere between work duties and personal life responsibilities this overlapping phenomenon makes achieving the balance between them an essential task for both managers of organizations who want to achieve high performance and employee himself/herself who wants to have a happy low stressful life. (Jeremy Hayman 2005) reported a scale to measure the level of this balance. The scale consisted of 15 items, divided into three factors: work interference with personal life, personal life interference with work, work/personal life enhancement.

The essentiality of achieving work-life balance increases regularly and became a worldwide phenomenon. This phenomenon has a growing complexity every day according to the change of the shared family roles between men and women and the increased number of working women. About $75 \%$ of 1000 participants responded to a survey made by community Business complaining from pressure caused by their unbalanced relation between their work and their personal life responsibilities (Allen TD 2001). Productivity at work affects strongly in a negative way by stress. The stress caused by unhealthy work-life balance causes also low enthusiasm, low motivation to achieve aspired performance and a decline in job satisfaction.

The majority of employees are concerned with the overwork time and the workload. According to (Bond S, Wise S 2003) applying work-life balance policies increase the employee's loyalty and increase self-esteem. Work-life balance could be defined as all the Procedures taken in order to achieve the balance between the employee's work and life in order to reduce the stress that happened because of overload of work duties and personal life responsibilities. As a must, Literature presented family-friendly policies that help employees to accomplish a balanced work life. According to (Clifton TJ, Shepard E 2004) increasing productivity could be happened by achieving work-life balance and also it could be a good tool for enhancing Job satisfaction. There are many aspects of Family-friendly policies like flexible working hours, easy regulations for emergencies pressing working weeks for unfinished work, having small rooms inside the workplace to take care of toddlers, evaluating the employee by achieved work whether he achieved it in work or at home if his work duties or some of it could be done in both places. Although implementing these policies couldn't assure the increasing productivity of all the employees, it will have a positive effect on many of them and will increase the productivity of the organization and that is related to the culture of the company and employees. Barnett \& Hyde (2001) see that work-life balance has a good effect on the employee's quality life. And that being involved in many roles help employee's 
in avoiding any negative effect of experiences happened in any role. Also, it helps in enhancing prosperity directly. According to Duxbury \& Higgins (2008), there is a strong relationship between the family responsibilities needed from the employee who is a parent and his/ her efficiency in doing his/her work duties. Likewise, new parents employees have considerably stressful times in their life and work more than those who haven't small children (Galinsky, Bond and Friedman 1996; Owen and Cox 1988) as they have extraordinary changes happened in their responsibilities and their priorities (Belsky and Pensky 1988; Levy-Shiff 1994; Feldman 2000). According to Anderson, Coffey, and Byerly (2002), work-related effects comprise job disaffection, absence, leaving work determination and stress. The conflict happened because of the unbalanced work life of the employee has a relationship with low organizational commitment (O'Driscoll, Ilgen and Hildreth 1992).

\section{Research Methods}

\section{Sample and Data Collection}

To test these hypotheses, the researcher made a field study using questionnaires to collect the data in a cross-sectional design. This approach was chosen to allow the researcher to evaluate organizational processes in the settings where he has minimal intrusion (McGrath 1982). Burgelman (1983) suggests that determining organizational orientations requires gauging the resource allocations that support these activities. However, the researcher was not able to access secondary source data which provided adequate details to accurately estimate constructs pertaining to different strategic orientations and to reflect the theoretical concepts employed. Despite some shortcomings, prior research (see Covin \& Slevin 1989; Naman \& Slevin 1993) indicates perceptual measures have a high correlation with objective measures and facilitate comparisons among firms in different industries (Zahra 1993; Zahra \& Covin 1993). A pool of items was generated for measuring each of the constructs using in-depth relevant literature search. A questionnaire was designed to ask various managers and owners for their perceptions on a range of organizational variables including the nature of inter-firm market collaboration and the link with business performance. This information was collected using a seven-point scale $(1=$ strongly disagree to $7=$ strongly agree $)$ in response to statements about these variables.

The researcher distributed 262 sets of questionnaires on the employees of Emaar Company, Al Medina company, Rana motors, Modern Multimedia company, Silver Star Auto Ltd. and AMS company which are located in Ghana. During the process, only 248 sets of the questionnaire (94.7\%) were received. Among the 248 sets of the questionnaire, only 240 sets of questionnaire were satisfactorily completed and tested by the Statistical Package for Social Science (SPSS) software as the other questionnaire sets were excluded because of incorrect answers or the duplicated results that are deemed invalid. there are $36.7 \%$ of female respondents and $63.3 \%$ of male respondents in this study. The majority of the respondents for this study are Ghanian (96.7\%) and only some of the respondents are from other nationalities $(3.3 \%)$. The respondents are required to rate the relationship between work-life balance and productivity in Ghana based on their own judgment of a given scale. 


\section{Statistical Analysis of the Survey}

Table (1) shows the outcome of the Pearson correlation. The value of the Pearson correlation coefficient between Productivity and poor performance in family roles is 0.402 at 0.000 significance level which means that there is a relation between productivity and poor performance in family roles.

Table (2) shows that The value of the Pearson correlation coefficient between Productivity and lack of good relationship with employees is 0.538 at 0.000 significance level which means that there is a relation between Productivity and lack of good relationship with employees.

Table (3) shows that The value of the Pearson correlation coefficient between Productivity and The poor working environment is 0.535 at 0.000 significance level which means that there is a relation between Productivity and The poor working environment.

Table (4) shows that The value of the Pearson correlation coefficient between Productivity and the decline in job satisfaction is 0.586 at 0.000 significance level which means that there is a relation between Productivity and the decline in job satisfaction.

Table (5) shows that The value of the Pearson correlation coefficient between Productivity and hard and exhausting work is 0.584 at 0.000 significance level which means that there is a relation between Productivity and hard and exhausting work.

Table (6) shows that the value of the Pearson correlation coefficient between Productivity and family-friendly policies is 0.556 at 0.000 significance level which means that there is a positive relation between Productivity and family-friendly policies.

Table(7) shows that the value of the Pearson correlation coefficient between Productivity and dedicating quality time to the family is 0.576 at 0.000 significance level which means that there is a positive relation between Productivity and dedicating quality time to family.

\section{Result}

Although the Ghanian people have very special characteristics like the ability to accommodate a difficult and hard lifestyle, the research found that poor performance in family roles causes poor productivity at work. Poor performance in family roles can be seen clearly in two aspects first: decreasing the time spent in taking care of the family and being exhausted not able to achieve the family roles appropriately. Also, the lack of a good relationship with employees whether it is between an Employee and his colleagues or it is between an employee and his direct and indirect managers lead to poor productivity at the end.

There are many aspects which affect the working environment like health and safety, working hours and security. According to the research employees who suffer from poor working environment their productivity is less than those who work in a good working environment. The results of declining job satisfaction and having hard and exhausting work are similar to 
the results shown above as they also have a negative effect on productivity

All of these hidden aspects cause Employee stress which can be increased to the level of burnout, resulting in lower productivity at work, a higher potential for stress-related health problems like Heart diseases, high blood pressure, and depression.

\section{Conclusion}

Ghanian people have special characteristics makes them a little bit different from other nationalities they are very sensitive to the strict orders and they deal with it in a reversed way affecting the work badly, they also need work which achieves a balance between their personal life and their duties in the workplace in order to achieve the companies productivity targets. The company which needs to achieve its goals quickly and efficiently must care about its employees' needs in the workplace and in their personal life too, aiming to have an active, self-motivated and high productive employee wouldn't come except by having a balanced and psychologically stable employee who doesn't have unbearable work in a stressful working climate .

\section{References}

Adams, G. A., King, L. A., \& King, D. W. (1996). Relationships of job and family involvement, family social support, and work-family conflict with job and life satisfaction. Journal of applied psychology, 81(4), 411. https://doi.org/10.1037/0021-9010.81.4.411

Allen, T. D. (2001). Family-supportive work environments: The role of organizational perceptions. Journal of vocational behavior, 58(3), 414-435. https://doi.org/10.1006/jvbe.2000.1774

Anderson, S. E., Coffey, B. S., \& Byerly, R. T. (2002). Formal organizational initiatives and informal workplace practices: Links to work-family conflict and job-related outcomes. Journal of management, 28(6), 787-810. https://doi.org/10.1016/S0149-2063(02)00190-3

Aryee, S. (1992). Antecedents and outcomes of work-family conflict among married professional women: Evidence from Singapore. Human relations, 45(8), 813-837. https://doi.org/10.1177/001872679204500804

Aryee, S., Luk, V., Leung, A., \& Lo, S. (1999). Role stressors, interrole conflict, and well-being: The moderating influence of spousal support and coping behaviors among employed parents in Hong Kong. Journal of Vocational Behavior, 54(2), 259-278. https://doi.org/10.1006/jvbe.1998.1667

Barnett, R. C., \& Hyde, J. S. (2001). Women, men, work, and family: An expansionist theory. American Psychologist, 56(10), 781. https://doi.org/10.1037/0003-066X.56.10.781

Belsky, J., \& Pensky, E. (1988). Marital change across the transition to parenthood. Marriage \& Family Review, 12(3-4), 133-156. https://doi.org/10.1300/J002v12n03_08

Bond, S., \& Wise, S. (2003). Family leave policies and devolution to the line. Personnel Review, 32(1), 58-72. https://doi.org/10.1108/00483480310454727 
Burgelman, R. A. (1983). A model of the interaction of strategic behavior, corporate context, and the concept of strategy. Academy of Management Review,8(1), 61-70. https://doi.org/10.5465/amr.1983.4287661

Burke, R. J., \& Greenglass, E. R. (1999). Work-family conflict, spouse support, and nursing staff well-being during organizational restructuring. Journal of occupational health psychology, 4(4), 327. https://doi.org/10.1037/1076-8998.4.4.327

Carlson, D. S., \& Kacmar, K. M. (2000). Work-family conflict in the organization: Do life role values make a difference?. Journal of Management, 26(5), 1031-1054. https://doi.org/10.1177/014920630002600502

Carlson, D. S., Kacmar, K. M., \& Williams, L. J. (2000). Construction and initial validation of a multidimensional measure of work-family conflict. Journal of Vocational Behavior, 56(2), 249-276. https://doi.org/10.1006/jvbe.1999.1713

Clifton, T. J., \& Shepard, E. (2004). Work and family programs and productivity: Estimates applying a production function model. International Journal of Manpower, 25(8), 714-728. https://doi.org/10.1108/01437720410570036

Covin, J. G., \& Slevin, D. P. (1989). Strategic management of small firms in hostile and benign environments. Strategic management journal, 10(1), 75-87. v

Covin, J. G., \& Slevin, D. P. (1993). A response to Zahra's "Critique and extension" of the Covin-Slevin entrepreneurship model. Entrepreneurship Theory and Practice, 17(4), 23-28. https://doi.org/10.1177/104225879301700402

Dex, S., \& Scheibl, F. (2001). Flexible and family-friendly working arrangements in UK-based SMEs: business cases. British Journal of Industrial Relations, 39(3), 411-431. https://doi.org/10.1111/1467-8543.00207

Duxbury, L. E., \& Higgins, C. (2008). Work-life balance in Australia in the new millennium: Rhetoric versus reality. Melbourne, Australia: Beaton Consulting.

Edwards, J. R., \& Rothbard, N. P. (2000). Mechanisms linking work and family: Clarifying the relationship between work and family constructs. Academy of management review, 25(1), 178-199. https://doi.org/10.5465/amr.2000.2791609

Feldman, R. (2000). Parents' convergence on sharing and marital satisfaction, father involvement, and parent-child relationship at the transition to parenthood. Infant Mental Health Journal: Official Publication of The World Association for Infant Mental Health, 21(3), 176-191. https://doi.org/10.1002/1097-0355(200007)21:3<176::AID-IMHJ3>3.0.CO;2-4

Felstead, A., Jewson, N., Phizacklea, A., \& Walters, S. (2002). Opportunities to work at home in the context of work-life balance. Human resource management journal, 12(1), 54-76. https://doi.org/10.1111/j.1748-8583.2002.tb00057.x

Frone, M. R., Barnes, G. M., \& Farrell, M. P. (1994). Relationship of work-family conflict to 
substance use among employed mothers: The role of negative affect. Journal of Marriage and the Family, 1019-1030. https://doi.org/10.2307/353610

Frone, M. R., Barnes, G. M., \& Farrell, M. P. (1994). Relationship of work-family conflict to substance use among employed mothers: The role of negative affect. Journal of Marriage and the Family, 1019-1030. https://doi.org/10.2307/353610

Frone, M. R., Yardley, J. K., \& Markel, K. S. (1997). Developing and testing an integrative model of the work-family interface. Journal of vocational behavior, 50(2), 145-167. https://doi.org/10.1006/jvbe.1996.1577

Fu, C. K., \& Shaffer, M. A. (2001). The tug of work and family: Direct and indirect domain-specific determinants of work-family conflict. Personnel review, 30(5), 502-522. https://doi.org/10.1108/EUM0000000005936

Galinsky, E., Bond, J. T., \& Friedman, D. E. (1996). The role of employers in addressing the needs of employed parents. Journal of social issues, 52(3), 111-136. https://doi.org/10.1111/j.1540-4560.1996.tb01582.x

Hayman, J. (2005). Psychometric assessment of an instrument designed to measure work-life balance. Research and practice in human resource management, 13(1), 85-91.

Hughes, J., \& Bozionelos, N. (2007). Work-life balance as a source of job dissatisfaction and withdrawal attitudes: An exploratory study on the views of male workers. Personnel Review, 36(1), 145-154. https://doi.org/10.1108/00483480710716768

McGrath, J. E., Martin, J., \& Kulka, R. A. (1982). Some quasi-rules for making judgment calls in research. Judgment calls in research, 103-118.

Naman, J. L., \& Slevin, D. P. (1993). Entrepreneurship and the concept of fit: A model and empirical tests. Strategic management journal, 14(2), 137-153. https://doi.org/10.1002/smj.4250140205

O'Driscoll, M. P., Ilgen, D. R., \& Hildreth, K. (1992). Time devoted to job and off-job activities, interrole conflict, and affective experiences. Journal of applied psychology, 77(3), 272. https://doi.org/10.1037/0021-9010.77.3.272

Owen, M. T., \& Cox, M. J. (1988). Maternal employment and the transition to parenthood. In Maternal employment and children's development (pp. 85-119). Springer, Boston, MA. https://doi.org/10.1007/978-1-4899-0830-8_4

Panisoara, G., \& Serban, M. (2013). Marital status and work-life balance. Procedia-Social and Behavioral Sciences, 78, 21-25. https://doi.org/10.1016/j.sbspro.2013.04.243

Rotondo, D. M., Carlson, D. S., \& Kincaid, J. F. (2003). Coping with multiple dimensions of work-family conflict. Personnel Review, 32(3), 275-296. https://doi.org/10.1108/00483480310467606

Simpson, P., McGrath, A., \& Savion, S. (1982). Myocyte hypertrophy in neonatal rat heart cultures and its regulation by serum and by catecholamines. Circulation research, 51(6), 
787-801. https://doi.org/10.1161/01.RES.51.6.787

Wise, S., \& Bond, S. (2003). Work-life policy: does it do exactly what it says on the tin?. Women in Management Review, 18(1/2), 20-31. https://doi.org/10.1108/09649420310462307

Wong, S. C. K., \& Ko, A. (2009). An exploratory study of understanding hotel employees' perception of work-life balance issues. International Journal of Hospitality Management, 28(2), 195-203. https://doi.org/10.1016/j.ijhm.2008.07.001

Zahra, S. A. (1993). Environment, corporate entrepreneurship, and financial performance: A taxonomic approach. Journal of business venturing, 8(4), 319-340. https://doi.org/10.1016/0883-9026(93)90003-N

Zahra, S. A., \& Covin, J. G. (1993). A business strategy, technology policy, and firm performance. Strategic management journal, 14(6), 451-478. https://doi.org/10.1002/smj.4250140605

\section{Tables}

Table (1). The outcome of the Pearson correlation (poor performance in family roles)

\begin{tabular}{c|c|c}
\hline \multicolumn{2}{c|}{ Pearson correlation coefficient } & poor performance in family roles \\
\hline \multirow{2}{*}{ Productivity } & Correlation & $* * 0,402$ \\
\cline { 2 - 3 } & significance & 0.00 \\
\hline & $* *$ Correlation is significant at the 0.05 level \\
\hline
\end{tabular}

Table (2). The outcome of the Pearson correlation (lack of good relationship with employees)

\begin{tabular}{l|c|c}
\hline \multicolumn{2}{c|}{ Pearson correlation coefficient } & $\begin{array}{c}\text { lack of good relationship with } \\
\text { employees }\end{array}$ \\
\hline \multirow{2}{*}{ Productivity } & Correlation & $* * 0.538$ \\
\cline { 2 - 3 } & significance & 0.00 \\
\hline \multicolumn{2}{|c}{$*$ Correlation is significant at the 0.05 level } \\
\hline
\end{tabular}

Table (3). The outcome of the Pearson correlation (The poor working environment)

\begin{tabular}{l|c|c}
\hline \multirow{2}{*}{ Pearson correlation coefficient } & The poor working environment \\
\hline \multirow{2}{*}{ Productivity } & Correlation & $* * 0.536$ \\
\cline { 2 - 3 } & significance & 0.00 \\
\hline & $* *$ Correlation is significant at the 0.05 level \\
\hline
\end{tabular}


Table (4). The outcome of the Pearson correlation (the decline in job satisfaction)

\begin{tabular}{c|c|c}
\hline \multicolumn{2}{c}{ Pearson correlation coefficient } & the decline in job satisfaction \\
\hline \multirow{2}{*}{ Productivity } & Correlation & $* * 0.586$ \\
\cline { 2 - 3 } & significance & 0.00 \\
\hline \multicolumn{3}{c}{$* *$ Correlation is significant at the 0.05 level } \\
\hline
\end{tabular}

Table (5). The outcome of the Pearson correlation (hard and exhausting work)

\begin{tabular}{c|c|c}
\hline \multicolumn{2}{c|}{ Pearson correlation coefficient } & hard and exhausting work \\
\hline \multirow{2}{*}{ Productivity } & Correlation & $* *$ \\
\cline { 2 - 3 } & significance & 0.584 \\
\hline \multicolumn{3}{c}{$*$ Correlation is significant at the 0.05 level } \\
\hline
\end{tabular}

Table (6) .The outcome of Pearson correlation (family-friendly policies)

\begin{tabular}{r|c|rr}
\hline \multicolumn{2}{|c|}{ Pearson correlation } & family-friendly policies \\
\hline \multirow{3}{*}{ Productivity } & correlation & \multicolumn{2}{c}{0.556} \\
\cline { 2 - 3 } & Significance & 0.000 \\
\hline
\end{tabular}

Table (7). The outcome of Pearson correlation (dedicating quality time to family)

\begin{tabular}{l|l|c}
\hline \multicolumn{2}{c|}{ Pearson correlation } & $\begin{array}{c}\text { dedicating quality time to } \\
\text { family }\end{array}$ \\
\hline \multirow{3}{*}{ Productivity } & correlation & 0.576 \\
\cline { 2 - 3 } & Significance & 0.000 \\
\hline
\end{tabular}

\section{Copyright Disclaimer}

Copyright for this article is retained by the author(s), with first publication rights granted to the journal.

This is an open-access article distributed under the terms and conditions of the Creative Commons Attribution license (http://creativecommons.org/licenses/by/4.0/). 